\title{
FORMULASI GEL EKSTRAK BATANG PEPAYA SEBAGAI ANTIBAKTERI TERHADAP BAKTERI STAPHYLOCOCCUSAUREUS
}

\author{
Amalia Eka Putri ${ }^{1)}$, Kristina Handayani ${ }^{2)}$ \\ Prodi S1 Farmasi, STIKes Karya Putra Bangsa Tulungagung, Jalan raya Tlungagung-Blitar 4 KM, \\ Sumbergempol Tulungagung \\ Alamat email: ekaputriamalia28@,gmail.com
}

\begin{abstract}
Infectious disease is an important disease in Indonesia. Infectious diseases can be caused by pathogenic microorganisms such as the bacterium Staphylococcus aureus ATCC 25923. Infectious diseases can be treated with antibiotics, but antibiotics now resistance. Therefore, other alternatives such as are needed papaya stem which can be used as an antibacterial against S.aureus ATCC 25923. The purpose of this study was to determine the antibacterial activity of papaya stem extract gel against Staphylococcus aureus ATCC 25923. Papaya stem sample extracted using a method soxhletation with $96 \%$ ethanol. The extract was made into a gel dosage with a concentration of $5 \%$. The positive control used is clindamycin and the negative control is gel without extract. The results of the papaya stem gel antibacterial activity test showed that the papaya stem gel had antibacterial activity against S.aureus ATCC 25923. The papaya stem extract gel preparation with a concentration of $5 \%$ had an average inhibition zone diameter of $18,56 \pm 0,51 \mathrm{~mm}$. The antibacterial activity is thought to come from the flavonoids, tannins, and saponins contained in the papaya stem fraction.
\end{abstract}

Keywords : Antibacterial, Carica papaya Linn, Gel, Staphylococcus aureus

\section{PENDAHULUAN}

Penyakit infeksi merupakan salah satu penyakit yang menjadi masalah kesehatan masyarakat yang penting, khususnya di negara berkembang seperti Indonesia. Penyakit infeksi dapat disebabkan dari mikroorganisme patogen seperti, bakteri Staphylococcus aureus ATCC 25923 (Kemenkes, 2011). Penyakit infeksi dapat diobati dengan pemberian antibiotik namun sekarang obat antibiotik mengalami resistensi karena faktor penggunaanya yang kurang tepat (Adzkie et al., 2017). Penggunaan obat antibiotik dari tumbuhan berkasiat obat dapat dijadikan sebagai alternatif lain, salah satu tanaman yang bisa digunakan sebagai obat tradisional yaitu tanaman pepaya (Primadiamanti et al., 2018).

Batang papaya merupakan salah satu bagian dari tanaman papaya yang dapat di manfaatkan sebagai antibakteri. Batang pepaya mengandung senyawa metabolit sekunder golongan saponin, tanin, dan flavonoid yang digunakan sebagai antibakteri (Simbolon et al., 2018). Ekstrak batang pepaya pada konsentrasi $1 \%$ memiliki aktivitas antibakteri paling efektif terhadap Staphylococcus aureus ATCC 25923 dengan diameter zona hambat sebesar $12 \mathrm{~mm}$ termasuk dalam kategori kuat Rahman et al., (2011).

Gel merupakan suatu sediaan jernih dengan penggunaan secara topikal yang banyak 
diminati oleh banyak masyarakat maupun konsumen industri dan kosmetika (Garg, D., S., \& A.K., 2002). Kelebihan penggunaan gel yaitu mudah dicuci, mudah meresap dalam kulit menimbulkan efek dingin pada kulit serta

\section{METODOLOGI PENELITIAN}

\section{Bahan dan alat}

Bahan yang digunakan dalam penelitian ini merupakan batang papaya segar, etanol $70 \%$, etanol 96\%, n-heksan, diklorometana, aquadestilata, magnesium (Mg), asam klorida ( $\mathrm{HCl})$ pekat, larutan feri klorida $\left(\mathrm{FeCl}_{3}\right) 1 \%$, Nutrient agar, Nutrient broth, $\mathrm{NaCl}$ fisiologis, Mc Farland, Propilenglikol, CMC, Gliserin, Staphylococcus aureus ATCC 25923 dan klindamisin.

Alat yang digunakan adalah ayakan mesh 80 , neraca analitik, oven, labu alas bulat, statif dan klem, kondensor, waterbatt, gelas beker, tabung reaksi, autoklaf (GEA YX2808), hot plate, cawan petri, kertas cakram, erlenmeyer, aluminium foil, use, tube, mikropipet, inkubator (model DNP Electro Thermal Incubator).

\section{Metode}

\section{Pembuatan simplisia}

Batang yang digunakan dalam penelitian ini adalah batang papaya yang berumur yaitu 1 tahun 3 bulan yang terdapat di kabupaten Blitar dan telah dilakukan determinasi. Batang dicuci sebanyak tiga kali dan dilakukan pemotongan dengan tebal 2-5 $\mathrm{cm}$. Batang papaya dikeringkan menggunakan oven pada suhu $50^{\circ} \mathrm{C}$. Batang papaya yang sudah kering digiling dan diayak menggunakan ayakan 80 mesh.

\section{Uji kadar air simplisia}

Uji kadar air serbuk batang pepaya dilakukan dengan memasukkan kurang lebih 10 g serbuk dan timbang seksama dalam wadah yang telah ditara. Dikeringkan pada suhu $105^{\circ} \mathrm{C}$ selama 5 jam dan ditimbang. Kadar air pada simplisia tidak lebih dari 10\% (Depkes, 2008).

\section{Proses ekstraksi}

Sampel diekstraksi menggunakan metode soxhletasi. Pelarut yang digunakan adalah etanol 96\% dengan perbandingan 1:20. memiliki pelepasan obat yang baik (Kaur \& Guleri, 2013). Tujuan penelitian ini adalah untuk mengetahui aktivitas antibakteri gel ekstrak batang pepaya terhadap S.aureus ATCC 25923.

Proses ekstraksi dihentikan apabila cairan yang menetes berubah menjadi jernih (empat kali sirkulasi). Ekstrak yang dihasilkan kemudian dipekatkan pada suhu $50^{\circ} \mathrm{C}$.

\section{Skinning fitokimia}

a. Tanin

Mengambil ekstrak sebanyak $2 \mathrm{~g}$ kemudian menambahkan etanol sampai terendam semuanya. Memindahkan sebanyak 1 $\mathrm{mL}$ larutan ke kedalam tabung reaksi dan ditambahkan 2-3 tetes larutan $\mathrm{FeCl}_{3} \quad 1 \%$. Hasil positif mengandung tanin ditunjukkan dengan terbentuknya warna hitam kebiruan atau hijau (Huda et al., 2019).

b. Flavonoid

Mengambil ekstrak sebanyak $1 \mathrm{~mL}$ kemudian mencampurkan dengan $3 \mathrm{~mL}$ etanol $70 \%$, kemudian dikocok, memanaskan dan mengkocok kembali kemudian menyaringnya. Filtrate yang diperoleh, kemudian menambahkan $\mathrm{Mg} 0,1 \mathrm{~g}$ dan 2 tetes $\mathrm{HCl}$ pekat. Terbentuknya warna merah, orange, atau hijau pada lapisan etanol menunjukkan adanya flavonoid (Huda et al., 2019).

\section{c. Saponin}

Mengambil ekstrak sebanyak $1 \mathrm{~mL}$ kemudian mencampur dan mendidihkan dengan $10 \mathrm{~mL}$ aquadestilata dalam penangas air. Mengocok filtrat dan didiamkan selama 15 menit. Terbentuknya busa yang stabil menunjukkan positif terdapat saponin (Alamsyah et al., 2014).

\section{Pembuatan sediaan gel}

Gel ekstrak batang pepaya dibuat dengan konsentrasi 5\%. Pembuatan sediaan gel dimulai dengan preparasi bahan meliputi ekstrak batang pepaya, CMC, gliserin, propilenglikol, dan aquadestilata. Ekstrak 
batang pepaya sebanyak $5 \mathrm{~g}$ dilarutkan dalam sebagian aquadestilata yang telah dipanaskan pada suhu $50^{\circ} \mathrm{C}$. Larutan ekstrak ditambah dengan CMC $3 \mathrm{~g}$ dan diaduk sampai homogen. Selanjutnya ditambahkan gliserin $10 \mathrm{~mL}$, propilenglikol $5 \mathrm{~mL}$, dan aquadestilata sampai volume $100 \mathrm{~mL}$ dengan pengadukan secara kontinyu sampai terbentuk sediaan gel ekstrak batang papaya. Formulasi sediaan gel dapat dilihat pada Tabel 1.

Tabel 1. Formulasi Sediaan Gel

\begin{tabular}{lc}
\hline \multicolumn{1}{c}{ Bahan } & Konsentrasi Gel \\
\hline $\begin{array}{l}\text { Ekstrak Batang } \\
\text { Pepaya }\end{array}$ & $5 \mathrm{~g}$ \\
\hline CMC & $3 \mathrm{~g}$ \\
\hline Gliserin & $10 \mathrm{~mL}$ \\
\hline Propilenglikol & $5 \mathrm{~mL}$ \\
\hline Aquadestilata ad & $100 \mathrm{~mL}$ \\
\hline
\end{tabular}

\section{Uji evaluasi sediaan gel}

a. Uji organoleptis

Uji organoleptis dilakukan secara visusal dan dilihat secara langsung bentuk, warna, dan bau dari sedian gel. Gel yang baik yaitu gel yang jernih dengan konsistensi setengah padat (Ansel, 2005).

b. Uji pH

Sediaan gel ditimbang sebanyak 1 gram dan dilarutkan dalam $100 \mathrm{~mL}$ akuadestilata dalam gelas beker. Larutan diukur pH-nya menggunakan $\mathrm{pH}$ indikator universal sebanyak tiga kali replikasi dan dihitung nilai rata-rata $\mathrm{pH}$ (Garg, D., S., \& A.K., 2002). Digunakan untuk mengetahui $\mathrm{pH}$ gel, apakah sesuai dengan $\mathrm{pH}$ kulit yaitu 5- 6,5 (Voigt, 1984).

c. Uji homogenitas

Diambil sediaan gel secukupnya, dioleskan pada gelas objek kemudian diraba dan digosok. Diamati susunan sedian pada gelas objek. Massa gel homogen ditunjukkan dengan tidak adanya bahan padat atau butiran pada kaca (Dewantari \& Sugihartini, 2015).

\section{d. Uji daya sebar}

Sediaan ditimbang sebanyak $500 \mathrm{mg}$, diletakkan ditengah kaca bulat berskala dan diletakkan kaca bulat lainnya yang telah ditimbang diatas gel selama 1 menit. Diukur diameter gel yang menyebar, kemudian ditambahkan beban $50 \mathrm{~g}$ didiamkan selama 1 menit. Dicatat diameter gel yang menyebar dan setelah penambahan beban $100 \mathrm{~g}, 150 \mathrm{~g}$, dan $200 \mathrm{~g}$. Daya sebar gel yang baik antara $5-7 \mathrm{~cm}$ (Dewantari \& Sugihartini, 2015).

e. Uji daya lekat

Sampel gel sebanyak $0,25 \quad \mathrm{~g}$ diletakkan diantara 2 objek glass pada alat uji daya lekat, ditekan dengan beban $1 \mathrm{~kg}$ selama 5 menit, kemudian beban diangkat dan pada alat uji dilepaskan beban $80 \mathrm{~g}$ serta dicatat waktu pelepasan gel. Sediaan gel yang baik memiliki waktu daya lekat lebih dari 4 detik (Dewantari \& Sugihartini, 2015).

\section{f. Uji daya proteksi}

Sediaan gel dioleskan pada kertas saring yang sebelumnya telah ditetesi fenoftalein. Kertas tersebut ditempelkan pada kertas saring lain dan kemudian ditetesi larutan $\mathrm{KOH} 0,1 \mathrm{~N}$. Diamati munculnya warna merah pada waktu detik ke 15, 30, 45, 60 serta menit ke 3 dan 5 . Gel yang baik tidak muncul bercak merah pada kertas saring (Widyantoro \& Sugihartini, 2015).

\section{Uji aktivitas antibakteri}

Uji aktivitas antibakteri gel ekstrak batang pepaya dilakukan menggunakan metode difusi cakram. Kertas cakram steril yang telah diresapi gel ekstrak batang pepaya masingmasing dengan konsentrasi 5\% ditempatkan pada permukaan media yang telah diinokulasikan Staphylococcus aureus ATCC 25923. Kontrol positif menggunakan $0,01 \%$ klindamisin. Kontrol negatif gel tanpa ekstrak. Selanjutnya diinkubasi pada suhu $37^{\circ} \mathrm{C}$. Hasil diamati dan diukur diameter zona hambat yang terbentuk. 


\section{HASIL DAN PEMBAHASAN}

\section{Determinasi, uji kadar air dan ekstraksi}

Hasil determinasi menunjukkan bahwa sampel yang digunakan benar batang pepaya (Carica Papaya Linn.). Hasil uji kadar air memenuhi persyaratan yaitu $7,79 \%$. Kadar air yang sesuai dengan syarat dapat mencegah pertumbuhan mikroorganisme sehingga simplisia batang pepaya dapat bertahan lama dalam penyimpanan (Depkes, 2008). Simplisia batang pepaya diekstrak menggunakan metode soxhletasi menghasilkan rendemen sebesar 5,39\%. Hasil uji dapat dilihat pada Tabel 2.

Tabel 2. Hasil Determinasi, Kadar Air dan Ekstraksi

\begin{tabular}{ccc}
\hline No. & Perlakuan & Hasil \\
\hline 1. & Determinasi & (Carica papaya \\
& Linn.) \\
2. & Uji Kadar Air & $7,7 \%$ \\
3. & Rendemplisia & $5,39 \%$ \\
\hline
\end{tabular}

\section{Skrinning fitokimia}

Skrinning fitokimia ekstrak batang pepaya bertujuan untuk memastikan keberadaan seyawa yang terkandung didalam batang papaya (Huda et al., 2019). Hasil skinning menunjukkan bahwa ekstak batang papaya mengandung senyawa flavonoid, saponin dan tanin seperti pada Tabel 3.

Tabel 3. Skrinning Fitokimia

\begin{tabular}{lc}
\hline Golongan Senyawa & Hasil \\
\hline Flavonoid & + \\
Saponin & + \\
Tanin & + \\
\hline
\end{tabular}

\section{Evaluasi sediaan gel}

Ekstrak diformulasikan menjadi gel ekstrak batang pepaya 5\% (Gambar 1.)..Hasil evaluasi yang didapatkan sudah sesuai dengan spesifikasi sediaan gel yang baik seperti pada Tabel 4.

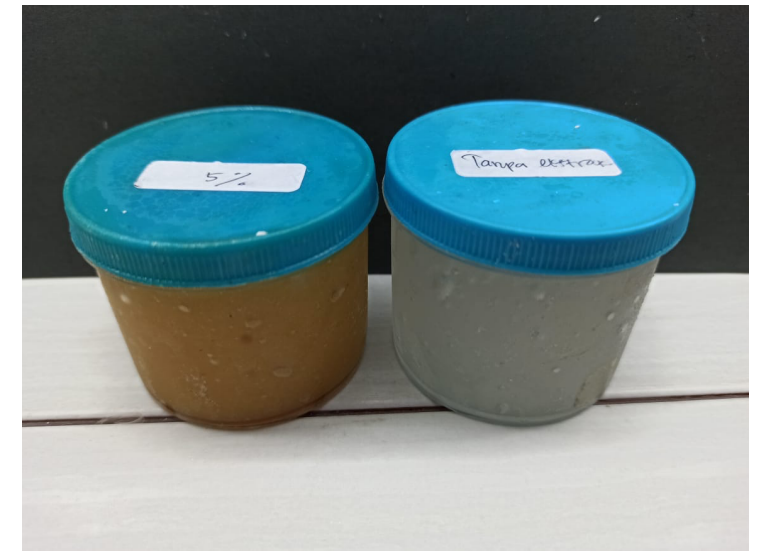

Gambar 1. Sediaan Gel Ekstrak Batang Pepaya 5\%

Tabel 4. Evaluasi Sediaan Gel

\begin{tabular}{lccc}
\hline \multirow{2}{*}{ Evaluasi } & \multicolumn{3}{c}{ Hari ke- } \\
\cline { 2 - 4 } organoleptis & $\begin{array}{c}\text { Bau khas } \\
\text { Coklat }\end{array}$ & $\begin{array}{c}\text { Bau khas } \\
\text { Coklat }\end{array}$ & $\begin{array}{c}\text { Bau khas } \\
\text { Coklat }\end{array}$ \\
\hline $\mathrm{pH}$ & 6 & 6 & 6 \\
\hline Homogenitas & Homogen & Homogen & Homogen \\
\hline Daya Sebar & 5 & 5,1 & 5,2 \\
\hline Daya Lekat & 6,3 & 7,1 & 7,3 \\
\hline $\begin{array}{l}\text { Daya } \\
\text { proteksi }\end{array}$ & Baik & Baik & Baik \\
\hline
\end{tabular}

\section{Uji aktivitas antibakteri}

Gel ekstrak batang pepaya kemudian diuji aktivitas antibakteri dengan menggunakan metode difusi cakram. Gel ekstrak batang papaya memiliki aktivias antibakteri terhadap Staphylococus aureus ATCC 25923 ditunjukkan dengan adanya daerah jernih disekitar kertas cakram (Gambar 2.). Diameter zona hambat gel ekstrak batang papaya memiliki rata-rata $18,56 \pm 0,51 \mathrm{~mm}$ masuk dalam kategori kuat. Hal tersebut diduga karena aktivitas dari senyawa saponin, tanin, dan flavonoid dalam batang pepaya yang digunakan sebagai antibakteri (Simbolon et al., 2018).

Hasil zona hambat kontrol negatif memiliki rata-rata sebesar $0 \pm 0,00 \mathrm{~mm}$. Hal ini menunjukkan bahwa aktivitas antibakeri yang dihasilkan berasal dari aktivitas ekstrak batang papaya dan basis gel tanpa ekstrak tidak memiliki aktivitas antibakteri terhadap Staphylococus aureus ATCC 25923. 


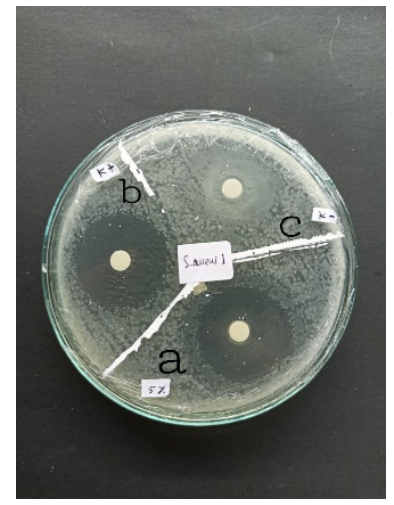

Gambar 2. Hasil Uji Aktivitas Antibakteri Ekstrak Batang Pepaya 5\% (a),Kontrol Positif (b) dan Kontrol Negatif (c)

Hasil dari klindamisin $0,01 \%$ yang digunakan sebagai kontrol positif, memiliki rata rata $23,99 \pm 0,31 \mathrm{~mm}$ masuk dalam kategori sangat kuat. Gel ekstrak batang papaya 5\% belum setara dengan aktivitas antibakteri klindamisin karena klindamisin merupakan senyawa murni sehingga diperlukan konsentrasi ekstrak yang lebih besar untuk menghasilkan diameter zona hambat yang setara dengan klindamisin. Hasil uji aktivitas antibakteri gel ekstrak batang disajikan pada (Tabel 5).

Nilai uji normalitas data menggunakan Shapiro Wilk didapatkan hasil nilai $\mathrm{p}=0,000(\mathrm{p}$ $\leq 0,05$ ) yang berarti data tidak berdistribusi normal. Ketidaknormalan data tersebut dikarenakan perbedaan variansi data yang jauh.
Pengujian dilanjutkan pada uji non parametrik Kruskal Wallis.

Tabel 5. Hasil Aktivitas Antibakteri

\begin{tabular}{|c|c|c|c|c|}
\hline \multirow[t]{2}{*}{ Sampel } & \multicolumn{3}{|c|}{$\begin{array}{l}\text { Diameter Zona } \\
\text { Hambat (mm) }\end{array}$} & \multirow{2}{*}{$\begin{array}{c}\text { Rata rata } \\
(\mathbf{m m}) \pm \\
\text { SD }\end{array}$} \\
\hline & $\mathbf{I}$ & II & III & \\
\hline $\begin{array}{l}\text { Gel ekstrak } \\
\text { batang } \\
\text { pepaya } \\
5 \%\end{array}$ & $\begin{array}{c}18,6 \\
7\end{array}$ & 18 & 19 & $\begin{array}{c}18,56 \pm \\
0,51\end{array}$ \\
\hline $\begin{array}{l}\text { Kontrol } \\
\text { Positif }\end{array}$ & $\begin{array}{c}23,6 \\
7\end{array}$ & 24,3 & 24 & $\begin{array}{c}23,99 \pm \\
0,31\end{array}$ \\
\hline $\begin{array}{l}\text { Kontrol } \\
\text { Negatif }\end{array}$ & 0 & 0 & 0 & $0 \pm 0,00$ \\
\hline
\end{tabular}

Hasil uji Kruskal Wallis didapatkan nilai $\mathrm{p}=0,000(\mathrm{p} \leq 0,05)$ yang berarti terdapat perbedaan bermakna pada diameter zona hambat terhadap Staphylococcus aureus ATCC 25923 dari kelompok perlakuan gel ekstrak batang pepaya. Pengujian dilanjutkan uji Mann Whitney untuk mengetahui adanya perbedaan bermakna antara dua kelompok perlakuan. Hasil uji Mann Whitney perbandingan antara gel ekstrak batang papaya dengan kelompok kontrol positif atau gel ekstrak batang papaya dengan kontrol negatif didapatkan nilai $\mathrm{p} \leq 0,05$ yang berarti terdapat perbedaan bermakna antar dua kelompok perlakuan.

\section{KESIMPULAN}

Gel ekstrak batang papaya memiliki aktivitas antibakteri terhadap bakteri Staphylococcus aureus ATCC 25923 yang ditandai dengan adanya zona hambat pada media tanam sebesar $18,56 \pm 0,51 \mathrm{~mm}$ masuk dalam kategori kuat.

\section{UCAPAN TERIMAKASIH}

Peneliti mengucapkan terimakasih kepada kedua orang tua, dosen, dan teman-teman yang sudah memberikan bantuannya dalam menyelesaikan penelitian ini.

\section{DAFTAR PUSTAKA}

Adzkie Muhammad, Nunuk Aries Nurulita, A. B. F. (2017) 'Uji Sensitivitas Antibiotik Terhadap Bakteri Penyebab Infeksi Saluran Kemih Pada Pasien Rawat Inap Di RSUD PROF. DR Margono Soekarjo Purwokerto', Pharmmacy, 14(2), pp. 247-263.

Alamsyah, H. K. and Widowati, I. W. dan A. S. (2014) 'Aktivitas Antibakteri Ekstrak Rumput Laut Sargassum cinereum (J.G. Agardh) DAari Perairan Pulau Panjang Jepara Terhadap Bakteri 
Escherichia coli Dan Staphylococcus epidermidis', Journal Of Marine Research, 3(2), pp. 6978.

Ansel, H.C., 2005. Pengantar Bentuk Sediaan Farmasi Edisi Kedua, diterjemahkan oleh Farida Ibrahim, Asmanizar, Iis Aisyah, Edisi keempat, 255-271, 607-608, 700, UI Press. Jakarta.

Cahyadi, J., Satriani, G. I. and Gusman, Ery Weliyadi, E. S. (2018) 'Skrining Fitokimia Ekstrak Buah Mangrove (Sonneratia alba) Bioenrichment Pakan Alami Salina', Jurnal Borneo Saintek, 1(3), pp. 33-39.

Depkes (2008) Farmakope Herbal Indonesia Edisi I. Jakarta: Departemen Kesehatan Republik Indonesia.

Dewantari, D.R. dan Sugihartini, N. 2015, Formulasi dan Uji Aktivitas Gel Ekstrak Daun Petai Cina (Leucaena glauca, Benth) sebagai Sediaan Obat Luka Bakar, Farmasains, 2(5): 217-222.

Dodyk Pranowo, Erliza Noor, L. H. dan A. M. (2016) 'Optimasi Ekstraksi Flavonoid Total Daun Gedi ( Abelmoschus manihot L .) Dan Uji Aktivitas Antioksidan', Bul. Littro, 27(1), pp. 37-46.

Garg, A., D. Aggarwal, S. Garg, dan A. K. Sigla. 2002. Spreading of Semisolid Formulation. Pharmaceutical Technology. USA.

Gazali, M., Nufus, H. and Nurjanah, Z. (2019) 'Ekaplorasi Senyawa Bioaktif Ekstrak Daun Nipah ( Nypa fruticans Wurmb ) Asal Pesisir Aceh Barat Sebagai Antioksidan', JPHPI, 22(1), pp. 155163.

Huda, C., Putri, A. E. and Sari, D. W. (2019) 'Uji aktivitas Fraksi Dari Maserat Zibethinus folium Terhadap Escherichia coli', Jurnal SainHealth, 3(1), pp. 7-14.

Insanu, M. and Ruslan, Komar Fidrianny, Irda Wijaya, S. (2011) 'Isolasi Flavonoid dari Daun Durian ( Durio Zibethinus Murr ., Bombacaceae )', Acta Pharmaceutica Indonesia, 36(1), pp. 6-10.

Kaur, L.P. and Guleri, T.K. 2013. Topical Gel: A Recent Approach for Novel Drug delivery, J.Biopharm.

Kemenkes (2011) Pedoman Umum Penggunaan Antibiotik. Jakarta: Menteri Kesehatan Republik Indonesia.

Lolongan, R. A., Waworuntu, O. and Christy N. Mintjelungan (2016) 'Uji Konsentrasi Hambat Minimum ( KHM ) Ekstrak Daun Pacar Air ( Impatiens balsamina L .) Terhadap Pertumbuhan Streptococcus mutans', Jurnal e-GiGi(eG), 4(2).

Primadiamanti, A., Winahyu, D. A. and Jaulin, A. (2018) 'Uji Efektivitas Sediaan Salep Batang Pepaya ( C arica Papaya L .) Sebagai Penyembuh Luka', Jurnal Farmasi Malahayati, 1(2), pp. 69-79.

Rahman, S., Imran, M. and Muhammad, N Hassan, N Chisthi, A K Khan, A F Sadozai, K S Khan, S. M. (2011) 'Antibacetial screening of leaves and stem of Carica papaya', Journal of Medicinal Plants Research Vol., 5(20), pp. 5167-5171.

Ratnani, R. D. and Hartati, Indah Anas, Yance Endah, Devi P. Khilyati, D. D. D. (2015) 'Standarisasi Spesifik Dan Non Spesifik Ekstraksi Hidrotropi Andrographolid Dari Sambiloto (Andrographis paniculata)', Prosiding Seminar Nasional Peluang Herbal Sebagai Alternatif Medicine, pp. 147155.

Simbolon Marita TM, Zalfiatri, Yelmira Hamzah, F. (2018) 'Pembuatan sabun transparan dengan penambahan ekstrak batang pepaya sebagai antibakteri’, Chempublish Journal, 3(2), pp. 57-68. doi: 10.22437/chp.v3i2.5713.

Voigt. 1984. Buku Ajar Teknologi Farmasi. Diterjemahkan oleh Soendani Noeroto S.,UGM Press, Yogyakarta. Hal: 337-338

Warokka, K. E., Wuisan, J. and Juliatri (2016) 'Uji Konsentrasi Hambat Minimum ( KHM ) Ekstrak Daun Binahong ( Anredera cordifolia Steenis ) Sebagai Antibakteri Terhadap Pertumbuhan Streptococcus mutans', Jurnal e-GiGi(eG), 4(2), pp. 155-159. 
Jurnal SainHealth Vol. 4 No. 2 Edisi September 2020

(C) Fakultas Ilmu Kesehatan Universitas Maarif Hasyim Latif Sidoarjo

p-ISSN : 2548-8333

e-ISSN : 2549-2586

Widiyantoro OB, Sugihartini N. Uji sifat fisik dan aktivitas ekstrak daun petai cina (Laucaena glauca, benth) dalam berbagai tipe basis salep sebagai obat luka bakar. Fakultas Farmasi Universitas Ahmad Dahlan. 2015; 12(2): 186-9 